\title{
A corpus-based approach to contemporary Irish writing: Ross O'Carroll-Kelly's use of like as a discourse marker
}

\author{
CAROLINA P. AMADOR-MORENO \\ Universidad de Extremadura
}

Received: 31 January 2012 / Accepted: 5 July 2012

\begin{abstract}
This paper analyses in quantitative and qualitative terms the representation of the discourse marker like in contemporary Irish English writing. A common feature of contemporary spoken English, the discourse marker like seems to have made its way into the English spoken in Ireland, as portrayed by contemporary Irish authors such as Paul Howard. Howard, whose narrative can be taken as an example of oral writing, has been acclaimed by critics as having an exceptionally fine ear for Dublin English, but what is this acclamation based on? The paper argues that the findings of corpus stylistics (comparative frequencies, distributions, etc.) document in a more systematic way what literary critics and readers may intuitively deduce. By analysing the syntactic and pragmatic behaviour of like in Howard's fictional discourse, this paper aims to show the value of the combination of computer methodology and literary interpretation in evaluating the representation of fictional dialect.
\end{abstract}

\section{KEYWORDS:}

Irish English, dialect, discourse markers, like, stylistics, Irish writing.

\section{RESUMEN}

Este artículo analiza en términos cuantitativos y cualitativos la representación del marcador del discurso like en la literatura irlandesa contemporánea. El marcador de discurso like, muy característico del inglés hablado en general, parece haberse abierto camino también en el inglés de Irlanda, tal y como recogen autores irlandeses contemporáneos como Paul Howard. Howard, cuya narrativa se puede tomar como ejemplo de escritura oral, ha sido aclamado por los críticos por su excepcional oído para retratar el inglés que se habla en Dublín. ¿Pero en qué se basa exactamente esta aclamación? Este trabajo sostiene que los resultados que aporta la estilística corpus (frecuencias comparativas, distribuciones, etc.) nos pueden servir para documentar de una manera más sistemática lo que los críticos literarios y los lectores pueden deducir intuitivamente. A través del análisis del comportamiento sintáctico y pragmático del marcador like en el discurso literario de Howard, este trabajo tiene como objetivo mostrar el valor de la combinación de métodos (estilísticos y computacionales) a la hora de evaluar la representación del dialecto ficticio.

PALABRAS CLAVE:

El inglés de Irlanda, dialecto, marcadores del discurso, like, estilística, literatura irlandesa.

*Address for correspondence: Carolina P. Amador-Moreno. Departamento de Filología Inglesa, Facultad de Filosofía y Letras, Avda. Universidad s/n, 10071, Cáceres, Spain. Tel: 0034927257000 Ext. 57515; E-mail: camador@unex.es 


\section{INTRODUCTION}

The study of texts has benefitted greatly from corpus linguistics through the development of a number of sophisticated linguistic and statistical techniques that provide the basis for empirical analyses (see Adolphs, 2006). Although the application of statistical analyses to the study of literary texts is not new (see for instance Halliday, 1971), the use of these techniques for literary analysis is becoming increasingly popular (Adolphs and Carter, 2002; Culpeper, 2002, 2009; Hori, 2004; Leech, 2008; Scott, 2006; Semino and Short, 2004; Stubbs, 2005). Sinclair's claim that computer-assisted analyses can offer a more objective view of language than that achieved by intuition alone (Sinclair, 2004) is indeed relevant for the study of literary texts, which has given rise to the growing field of study known as Corpus Stylistics (a discussion of the link between corpus linguistics and literary stylistics is offered in Mahlberg, 2007b). At their plenary address to the Inter-Varietal Applied Corpus Studies (IVACS) Conference in Nottingham in 2006, Stockwell and Wynne drew attention to the fact that, despite the pessimism with which it was initially received by some scholars, the general field of Corpus Stylistics satisfies the demand for empirical evidence, and allows for transparent and systematic means of interrogating literary critical positions (Stockwell and Wynne, 2006). Indeed, as Louw argues, any intuition readers, investigators or critics may have in relation to a particular creative text, "is either corroborated or revised by the evidence provided by the corpus” (Louw, 1997: 243). In that sense, rather than as a replacement for other more traditional approaches to the language of literature, corpus analysis can be seen as a complement to literary analysis.

Corpus stylistics studies have on the whole focused on facilitating interpretations of a literary work or collection of works by describing an author's or a text's most representative features. Stubbs (2005), for example, analyses recurrent patterns and word frequency in Joseph Conrad's Heart of Darkness. Similarly, Starcke's (2006) exploration of phraseological units in Jane Austen's novel Persuasion shows how computer-assisted techniques can add new meanings to texts with a long tradition of literary criticism, and Mahlberg (2007a) studies the significance of clusters in Dickens' work, by comparing his literary language with that found in a corpus of $19^{\text {th }}$ century writing. Culpeper (2009) concentrates on character-talk in Romeo and Juliet, by carrying out a keyness analysis which allows him to compare different characters' statistically-based similarities and differences, and O’Halloran (2008) uses Street Song, by Fleur Adcock, as data to discuss how a literary text works to establish itself in the minds of both the literary critic and the reader. However, although the use of corpus-analytic techniques can certainly contribute new insights and provide statistical evidence for the interpretation of established texts and authors, they can also assist in the evaluation of emergent writers and their texts.

Also, from a variationist perspective, the use of computerised corpora has also facilitated the study of language variation and change using literary data. Culpeper and Kytö 
(1999) discuss diachronic findings (their data covers the period from 1560 to 1760), whereas Cohen Minnick's synchronic (2001) analysis compares the features of African American Vernacular English that characterise Jim's speech in Huckleberry Finn with those features documented by other researchers and in the Linguistic Atlas of the Middle and South Atlantic States (LAMSAS). This type of variational approach is also taken by Tamasi (2001), who analyses the speech of Huck Finn in both The Adventures of Tom Sawyer and The Adventures of Huckleberry Finn in order to observe how Twain's use of literary dialect develops over time. Tamasi's (2001) and Cohen Minick’s (2001) studies are among the few, so far, to have applied the tools of corpus linguistics to the analysis of literary dialect ${ }^{1}$, an area of study which the present paper aims to be a small contribution to.

By analysing the fictional discourse of contemporary Irish writer Paul Howard, the present paper aims to show that corpora and corpus-analytic tools can be very useful not only in determining the style of an author in a present-day context, but also in delineating the construction of what is perceived by that author as proper to the particular language variety depicted in his novels, that is, the English spoken in Ireland, or Irish English (IrE). In that sense, the purpose of the present study is also to add to the description of this particular variety of English and its current status.

By examining the use of like as a discourse marker, which, in accordance with Schiffrin's definition, is understood here as "sequentially dependent elements that bracket units of talk" (Schiffrin, 1987: 31) ${ }^{2}$, this paper will focus on how corpus study techniques can offer interesting insights into the use of IrE features in fiction. The focus on the discourse marker like here is triggered by its high frequency (49.9\% of all uses of like in the novel), and its potential stylistic significance in Paul Howard's novel The Curious Incident of the Dog in the Nightdress. As Halliday puts it, "[if] in the selections [the writer] has made there is an unexpected pattern of frequency distributions, and this turns out to be motivated, it seems pointless to argue that such a phenomena could not possibly be significant” (1971: 343).

As pointed out by Carter (1999; 2004), Simpson (2004), and others, literary language is socially and culturally contingent. Thus, throughout the paper, the term literary language is meant in the sense of fictional language, not as a set of features that are authorised as "literary" (see also Leech, 2008: 7-8). The paper begins with a brief discussion of the (re)presentation of the spoken mode in fiction, followed by a corpus-based study of The Curious Incident of the Dog in the Nightdress. The results derived from this study seem to point in the direction of an attempt to reproduce the use of the discourse marker like in fictional writing. This particular discourse marker is taken as an example of a linguistic feature that is generally associated with the spoken mode. Thus, it is argued that in his attempt to reproduce the spoken variety of the language as used in spontaneous conversation in Ireland, Howard draws on what he hears around him. The combination of a quantitative analysis that allows us to observe general trends in the data, and a more qualitative focus, 
shows how linguistic means contribute towards the construction of the atmosphere of the novel.

\section{THE SPOKEN MODE IN WRITING}

Many literary texts show a high degree of orality by displaying features of the spoken mode often found in everyday conversation. Whereas it is evident those fictional representations of conversation creatively exploit linguistic features which may be characteristic of the spoken language, this is not to say that fictional dialogue and naturally occurring conversation are identical types of communication (Simpson, 1997: 164). However, it is undeniable that as readers/viewers/spectators we tend to react in certain ways depending on how convincing the rendering of spokenness may be in a play, a film or a novel (Amador Moreno and Nunes, 2009). A period film, for example, might be immediately rejected by its audience if it contains linguistic anachronisms, or a play might cause a negative reaction if the language (re)presented in it is considered to be unrealistic. An example of this sensitivity is the negative reaction to John M. Synge's play The Playboy of the Western World in the context of the Irish Literary Revival, where the language of the play, among other issues, caused a significant portion of the audience to riot (see Kiberd, 1995: 174-175).

In her comparative study of spoken and written narratives by the same narrator, Tannen (1980) concludes that written narratives tend to contain a high degree of features that are proper to the spoken mode. Johnstone (1991) also makes the point that discourse-level features, apart from signalling orality, are often used to mark narrators' and characters' speech as dialectal: "in addition to or instead of respellings or non-standard lexis or syntax, [writers] use such things as non-standard or regionally marked patterns of cohesion, forms of reference and address, strategies of politeness, and discourse markers” (1991: 462).

Discourse markers (henceforth DM), as pointed out by McCarthy (1993), play a major role in our judgment of the degree of spokenness present in a particular text. Indeed, the presence of DMs in written narratives often determines the distance between reader and writer, as much as it does in ordinary conversation among interlocutors. This will be examined below in the context of Howard's narrative, who, in keeping with the long Irish tradition of story-telling, manages to reflect the oral-fictional element through the use of markers of the spoken mode such as like. A conscious effort to capture the features of contemporary spoken IrE, particularly those associated with the age and social provenance of his characters, can be observed by "first sight" reading ("first sight" in this case meaning "not backed up by data”). However, a quantitative approach to his writing provides statistical evidence which may complement whatever impressions have been obtained after the first reading. This, in turn, may lead to judgments based entirely on intuitions. 
The use of the DM like, as will be discussed below, is by no means exclusive to the variety of English spoken in Ireland. However, the fact that it is one of the most salient features in the text under scrutiny is significant: first of all because it appears to indicate that it is gaining attention and becoming widespread in Dublin, and secondly, because the more frequent an item is, the greater is its significance for the structure or the content of a text.

The importance of being aware of the range of possible choices open to language users (and, by extension, writers) at a particular point in time is noted by Baker (2007: 48) in his discussion of the concepts of frequency and dispersion. Evidently, despite the consistent appearance of certain features of IrE in the writing of Irish authors throughout time, the fact that some features are portrayed in the work of some periods in particular, and not in others, or that a number of features are used with a certain meaning by some authors but with a different meaning by older generations of writers, is a clear indicator that authors record in writing what they hear around them. As Schneider (2002) puts it, the written record in these cases can be taken to act as a filter, as it renders "speech forms that a typical member of a given speech community might have uttered with some degree of likelihood, representative of the everyday communication in this community” (Schneider, 2002: 67). In that sense, whereas it could be argued that the occurrence of other IrE DMs such as troth, or sure (Amador Moreno, 2005) in the novels of nineteenth-century/early twenty-century Irish writers might be "a representation of a speech act that we would have liked to have listened to and recorded acoustically and that without the written record would have been lost altogether" (Schneider, ibid.), it would not have been possible to find like as a DM (with the meaning it has nowadays), because such a choice simply was not available to speakers or writers at that time.

Paul Howard's style has been praised by critics on account of his ability to capture the spontaneity of spoken IrE. A first approach to any of the novels belonging to his Ross O'Carroll-Kelly series reveals an acute awareness of accent and dialect. In that sense, his success as a writer is no doubt connected to the fact that his novels can be read as if one was "listening" to the story. The Curious Incident of the Dog in the Nightdress, which belongs to that series, is an example of a written text that imitates the spoken style. The story, as with all the other novels belonging to the series, is presented as the oral narrative of the protagonist, Ross [O'Carroll-Kelly], "as told to Paul Howard”. A brief description of the series should enable readers who are not familiar with Howard's writing to follow the discussion of his fictional rendering of the English spoken in Dublin more easily.

\section{TEXT DESCRIPTION AND DATA SOURCE}

The character/pseudonym of ROCK (Ross O'Carroll-Kelly) was created by Howard as part of a weekly column in the Irish Sunday Tribune which started in 1998 and still appears in The Irish Times. The column was adapted into a whole series, which consists of nine novels, 
displaying a type of humorous narrative that is sometimes labeled as "male popular fiction" due to its political incorrectness in relation to issues such as class, gender or ethnicity. They satirize the stereotypical culture of prosperous South-side Dublin as opposed to the more urban and less prestigious North-side Dublin. This satirisation is achieved in part through linguistic means. Whereas Ross and his friends represent what Hickey (2005: 7-8) refers to as "new Dublin English", other characters from the north side use "local Dublin English". The north-south divide that is represented in the novels is based on the linguistic differentiation, analysed by Hickey (2005), between speakers generally coming from areas of high social prestige -those representing "a section of the population which does not want to be identified with all too localised forms of Dublin English", and those who "show strongest identification with traditional conservative Dublin life of which the popular accent is very much a part" (Hickey, 2005: 6-7).

Among the features pertaining to spoken language, The Curious Incident of the Dog in the Nightdress (2005), like the rest of the novels in the series, contains:

1. Dialectal pronunciation (for example, spoice boorger an' chips wi' cuddy sorce [spice burger and chips with curry sauce]),

2. Slang (gaff [place, house]),

3. Taboo language (What the fock do you want?),

4. In-group rhyming creations, often formed from colloquial pronunciations or near

5. Homophones: for example Jo (Jo maxi) -meaning taxi; Tone (Wolfetone)- meaning phone.

The story is presented in the form of a first person narration from Ross's perspective and it starts off at his wedding reception, shortly after all the guests (including the bride and her family) have discovered that Ross has an illegitimate child from a "fling" he had as a teenager while he was taking part in what he describes as "an exchange programme with a difference”, whereby students from his school spent some time living with families in the north side of Dublin, and the students from those families went to live in the south side.

This novel, which contains 91,839 words in total, is representative of the style employed by its author, and the type of corpus-analytic exploration described below may provide some interesting insights into how the narrative voice is constructed, and how this construction may in fact affect the reader's evaluation of its effects, once certain recurrent forms such as the DM like are taken into account. 


\section{METHOD AND RESULTS}

To investigate how words are used in the corpus, two of the most common tools in the Wordsmith Tools suite (Scott 1999) were employed: WordList and Concord. The first step in the analysis was to extract the novel's most frequent words. Applying the WordList tool, a list of the most frequent words in the text was generated, whereas the Concord tool was used to see the words in context. Once the frequency list has been provided, Concord returns examples of the search item in its context of use (as is well known, these are presented as concordance lines, which allow us to view all tokens in context for a detailed qualitative analysis). Frequency lists provide empirical evidence for the significance of individual items in the text. The frequency ranking of the words found to occur in the corpus is shown below. The left-hand part of Figure 1 shows that, with 4,407 occurrences, and is the most frequent word in the novel.

\begin{tabular}{llll}
\hline $\mathbf{N}$ & Word & Freq. & $\%$ \\
1 & And & 4,407 & 4,55 \\
2 & I & 4,378 & 4,52 \\
3 & The & 3,592 & 3,70 \\
4 & To & 2,262 & 2,33 \\
5 & Like & 1,913 & 1,97 \\
6 & A & 1,761 & 1,82 \\
7 & He & 1,689 & 1,74 \\
8 & Of & 1,632 & 1,68 \\
9 & You & 1,522 & 1,57 \\
10 & It & 1,485 & 1,53 \\
\hline 11 & In & 1,241 & 1,28 \\
12 & She & 1,089 & 1,12 \\
13 & Roysh & 1,075 & 1,11 \\
14 & That & 1,051 & 1,08 \\
15 & Goes & 985 & 1,02 \\
\hline & Fine & & \\
\hline
\end{tabular}

Figure 1. Wordlist of single words in CIDN

In order to determine the statistical significance of the frequencies, a comparison between frequency lists in our corpus and a reference corpus is often useful. This way one is 
able to determine whether some of the words occur more often than expected in the corpus under analysis. As Römer (2006: 95) indicates, “the comparison of a frequency wordlist from a small and specialised corpus with a frequency wordlist based on a larger reference corpus can highlight items in the smaller corpus [...] that are unexpectedly common and that are likely to characterise the texts in this corpus”.

A comparison of the ten most frequent words in the Limerick Corpus of Irish English (LCIE), a corpus of general spoken IrE (Farr, Murphy and O'Keeffe, 2002), and The Curious Incident of the Dog in the Nightdress (CIDN) reveals some interesting findings (Amador Moreno and O’Keeffe, 2009). Table 1 shows the ten most frequent words in the LCIE and the CIDN corpus:

\begin{tabular}{|l|l|l|}
\hline \multicolumn{1}{|c|}{ N } & \multicolumn{1}{|c|}{ LCIE } & CIDN \\
\hline 1 & the & and \\
\hline 2 & I & I \\
\hline 3 & you & the \\
\hline 4 & and & to \\
\hline 5 & to & like \\
\hline 6 & it & a \\
\hline 7 & a & he \\
\hline 8 & that & of \\
\hline 9 & of & you \\
\hline 10 & yeah & it \\
\hline
\end{tabular}

Table 1. Ten most frequent words in the LCIE and CIDN

Some of the items found in the CIDN corpus have similar rates of occurrence in LCIE (I, the, $a$, to), whereas others show a higher rate (and, it, you). Both lists contain the personal pronouns $I$ and you, which signal spoken interaction. However, the occurrence of you ranks higher in the LCIE than in the novel. This suggests that in the rendering of spokenness in the novel, the speaker/narrator does not resort to listener response tokens as much as it is often done in real spoken language (see McCarthy, 2002). The same, in fact, can be said of the occurrence of yeah in LCIE, an item that is not among the top ten words in CIDN. A striking difference in this comparison is the high rate of occurrence of like in the CIDN list, which appears at number fourteen in the LCIE. However, as will be discussed below, it is the use of like as a DM that accounts for this high frequency in both corpora.

In general word-frequency lists, high frequency words tend to be grammatical words, as can also be observed in Table 1. Our first assumption in relation to the item like might be that it is used as a preposition or a conjunction. A concordance search of its occurrence in CIDN provides an immediate "picture" of the function of this word in the novel. As opposed to what 
might have been expected, a significant high percentage of the concordance lines for like do not show grammatical uses of this word, but are used instead as a DM.

As is well known, "a concordance is simply a list of all the occurrences of a particular search term in a corpus, presented within the context that they occur in” (Baker, 2007: 71), Concordance lines generally present the search word in the middle of the screen and some context on the left and on the right. However, all occurrences of a word are presented indiscriminately unless the text is tagged (see Semino and Short, 2004). A concordance of the word like is given in Figure 2, which shows the first 15 instances of this item in random order.

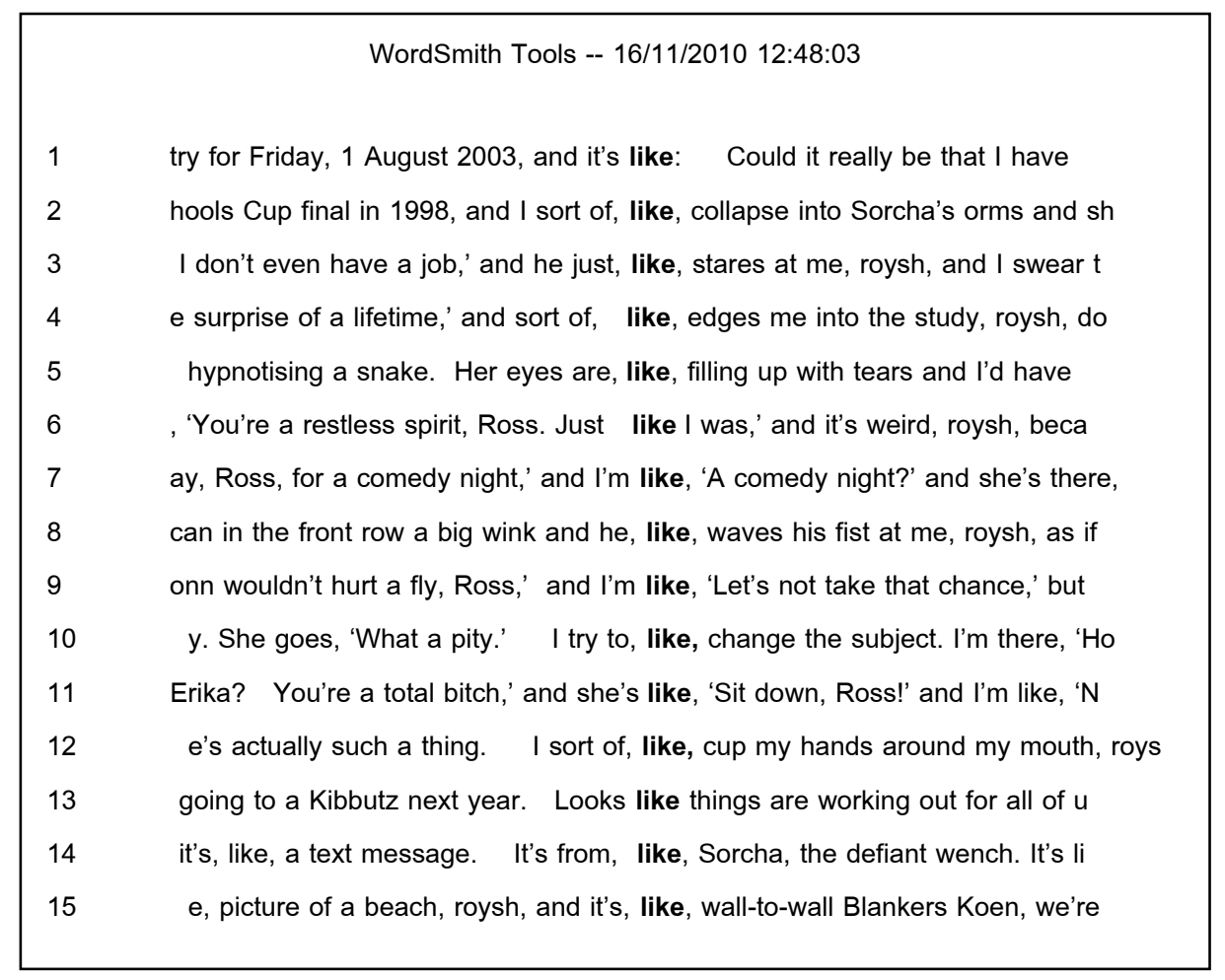

Figure 2. Concordance lines of like

As Figure 2 shows, although the predominant function of like appears to be as a DM, some of the examples returned by the software include the verb like as well as other conventional grammatical uses such as prepositions, conjunctions, or adverbials (see lines 6 and 13, for example). However, since what we are interested in, for the issue at hand, is determining the high occurrence of like as a DM, the examples where it functions as verb, preposition, conjunction or straight adverb were excluded from this quantitative analysis. A close analysis of the patterns reveals certain collocations which are worth examining. Thus, the overall concordance output shows that the co-occurrence of be + like is a recurrent one, something which is further buttressed by looking at a frequency list for clusters of words. The analysis of clusters allows us to identify the sequences of multi-word units that have the highest frequency. By specifying the cluster size as 2, we notice that I'm like, he's like and 
she's like are among the most frequent. These quotative uses of like (as discussed by Ferrara and Bell, 1995; and Romaine and Lange, 1991) foreground reported speech and thought, and therefore, would constitute a single category on their own (see also Buchstaller and D'Arcy, 2009). This particular collocational pattern (be + like) is considered a case of grammaticalisation, where a single processing unit becomes automated (Tagliamonte and D'Arcy, 2004). The issue of this particular use of like, though closely related to discoursemarking, falls outside the scope of this paper. Given its nature, this category deserves to be analysed separately.

In the remainder of the present paper, then, we concentrate on the uses of like which exclude all the kinds of tokens discussed so far. Once the tokens of like as a lexical verb, adverbial, preposition, suffix, conjunction and quotative are discarded, the DM like accounts for as much as $49.9 \%$ of the occurrences of like as a whole. A close look at these concordance lines shows that certain grammatical environments favour this type of like, which occurs in six main positions:

1. Preceding (and within) a noun phrase, e.g. ... "Excuse me? You've got, like, a child?”...

2. With numeral/quantitative expressions, e.g. ... JP is walking, like, twenty yords ahead of the rest of us.

3. Preceding (and within) an adjective-modified noun phrase, e.g. ... she gives me this, like, evil smile....

4. Preceding (and within) a prepositional phrase, e.g. ... I heard that from Wendy, who's, like, in the Institute...

5. Preceding an adverbial phrase, e.g. ... JP is, like, holding her hand and talking to her really, like, seriously.

6. With verb phrases, e.g. ... and the borman just, like, shrugs and focks off down the other end of the bor.

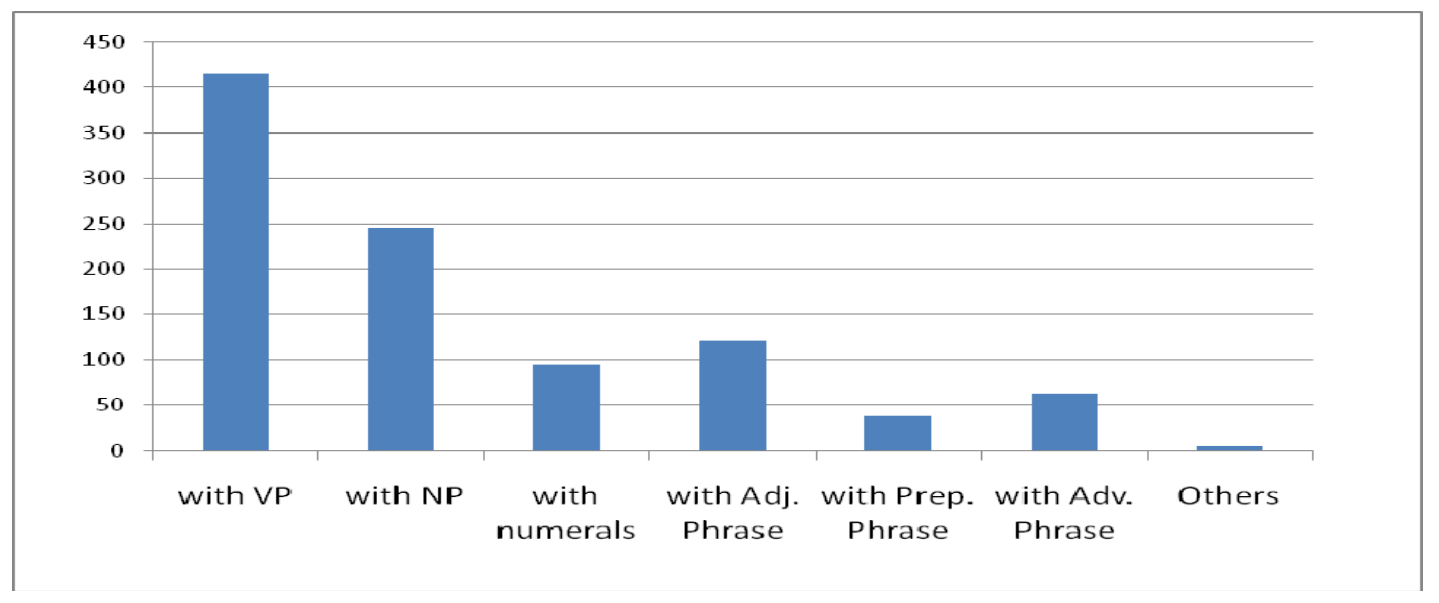

Figure 3. Occurrence of like in different grammatical environments 
Some of the examples found in the novel would not fall within any of the categories mentioned above (e.g. “[...suddenly feeling all, like, I don’t know, fatherly, I suppose”; “At, like - OH! MY! GOD! - midnight?”). These are grouped under “others” in Figure 3, which shows the total number of tokens in each grammatical environment.

Interestingly, the majority of these examples occur in sentence-medial position. Only two examples of clause-final like (“That's been bled from an engine, like?”) and one example of clause-initial (Like all those gospel songs he knows) are found in the novel. This, as will be discussed further below, is interesting in the light of research carried out by Kallen (2006) and White (2008), who draw attention to the occurrence of clause-final like in their data ("So when we were doing religion class they were doing religion class as well like") ${ }^{3}$. In the fictional context represented in the novel, and given Howard's awareness of social/geographical differences, the fact that sentence-medial position like is favoured by the characters in the novel confirms Hickey's argument that "fashionable" Dublin speakers actively try to distance themselves from local Dublin speakers, as will be discussed below. In addition, our data shows that split forms ("I don't, like, answer her") are also common, and that there seems to be a preference for certain collocates. Thus, the collocation of like with sort of, just and so (e.g. “... and he sort of, like, grabs me by the orm, roysh...”; “...It's just, like, unpacking now, then decorating...”; “...Oh MY God! This is, like, SO embarrassing...”) is certainly consistent throughout the novel.

\section{EVALUATION OF EVIDENCE: LIKE AS A DISCOURSE MARKER IN IRISH ENGLISH}

The use of like as a DM has attracted much scholarly attention over the last two decades. Several studies have considered its use in American English (Schourup, 1985, Dailey-O'Cain, 1996), the English of Canada (D’Arcy, 2005), New Zealand (Dragger, 2006), England (Andersen, 1997; Levey, 2006), N. England and Scotland (Macaulay, 2005; Miller and Weinert, 1995). Its use in IrE has also been briefly mentioned in research carried out by Farr and O’Keeffe (2002), Kallen (2006), Murphy (2004, 2010), O’Keeffe (2005), and White (2008), while Schweinberger (forthcoming) is a comparative study. In addition, no attention has been paid so far to how or why this feature is represented in Irish writing.

\subsection{Position of like}

As pointed out above, the greatest difference between what some scholars (cf. Hickey, 2007: 376; Kallen, 2006) have noticed in relation to IrE data, and a small corpus like CIDN is that in the latter the highest occurrence of discourse-marking like is in mid-clause position, which seems to imply that "element-final” like (as Kallen, 2006 calls it) is not as commonly heard in Dublin as in the rest of Ireland, or that perhaps it is seen as unfashionable by the south-Dublin 
kids portrayed in the novel -according to Howard's perception ${ }^{4}$. In the absence of a specific corpus of spoken Dublin English, however, no further conclusions can be reached yet. Admittedly, that this might be a more popular use outside of Dublin would be vouched for by the fact that only one of the over 400 tokens of utterance-final like discussed in Kallen (2006) comes from this area. Evidence of its occurrence outside of Dublin is also found in the data analysed in Amador Moreno and O’Keeffe (2009), where 81\% of the examples of the DM like were in utterance/clause-marginal (that is clause-initial/clause-final) position, and only 19\% appeared in mid-clause position (see Figure 4).

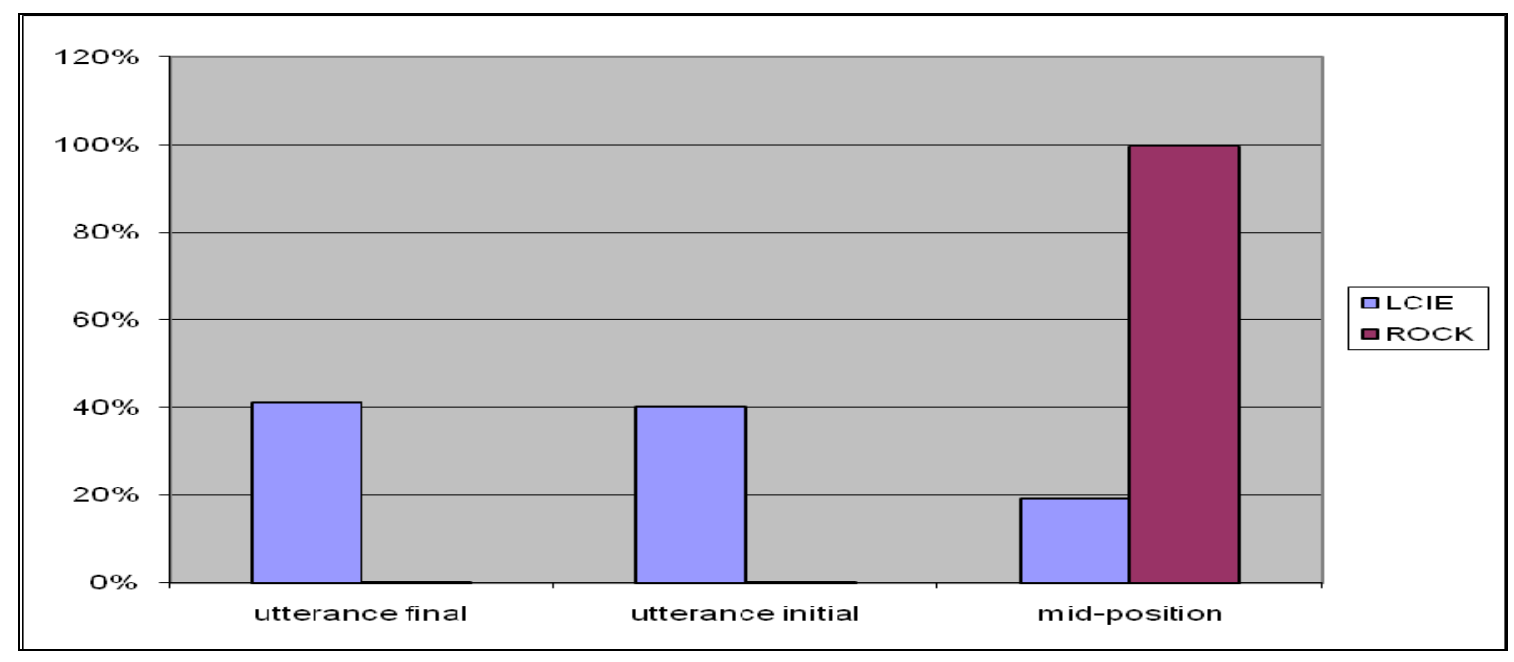

Figure 4. Comparison of positional occurrence of like in LCIE and CIDN

By the same token, most of the examples cited in Hickey (2007: 376) from the TapeRecorded Survey of Hiberno-English Speech, collected in the early 70s and 80s also show "element-final" position, as do the results found in ongoing research by Schweinberger. The main difference between this and mid-clause position like is that utterance/clause-final like "does not precede the information to which it is attached, but follows it. Positionally it may occur within an utterance or may appear more like a conversational tag, attached at the end" (Kallen, 2006: 12). The majority of the examples found in the novel, though, are of midclause like, which precedes the element(s) highlighted by the speaker, drawing attention to the information that follows.

\subsection{Functions of like}

A well known feature of American English (AmE) (Romaine and Lange, 1991), the use of like as a DM is known to have disseminated rapidly in several varieties of English (particularly in urban varieties). In their study of Indian English, Philipine English, Irish English and East African English, Siemund et al. (2009) found this feature to have spread significantly. As pointed out by Levey (2006: 415) teenagers are often cited as being in the 
vanguard: "discourse markers such as like constitute a potential pragmatic resource on which adolescents can draw to make sociosymbolic declarations of youth” (Levey, 2006: 422). This DM, which, as Andersen (1998: 150) notes, is often frowned upon and commonly denounced as "incorrect", redundant and without meaning, has been shown to have many different functions in conversation, most of which are present in Howard's rendering of Dublin speech.

Fuzzy thought, for example, is signaled in examples such as "[...] with all these bottles with, like, funny-coloured liquids in them, bubbling away over all these, like, Bunsen burners" (my italics), where the narrator, Ross, seems to be searching for the appropriate expression (Jücker and Smith, 1998: 188), as if indicating "this is a term which may not be the most appropriate to use or which is unusual for me to utter" (Andersen, 2000: 31). This is even more evident in, for example, “I'm like, 'Hey, how the fock are you, Trevor?' and I'm sort of, like, subconsciously -if that's the word- making my voice deeper, just so he doesn't get any ideas", where the metalinguistic comment "if that's the word" emphasises the search for the right term. Given that, as Figure 3 shows, it is mainly verb phrases that are preceded by like, it seems that this search for the right term in the novel mostly affects the description of actions.

This type of like as a DM is also used for exemplification in the novel, as in the example "I'm thinking of going back playing rugby next year, maybe for, like, Greystones", where, as Schourup (1985) suggests, like may be rendered as "for instance". In other contexts, it is used to introduce an explanation, an alternative term, or to rephrase something, as in the example "I get this, like, feeling of excitement in my stomach, butterflies, I suppose you'd have to say", where the narrator adds some more information (butterflies, I suppose you'd have to say) as if indicating he realises his initial formulation is not precise enough (Müller, 2005). The affinity of this use with like as a hesitation device is discussed in Andersen (2000, 2001) and Miller and Weinert (1995).

Another function of the DM like which is evident in the corpus is focusing. As pointed out by Miller and Weinert (1995), Levey (2006) and others, like can operate as a focusing device, often highlighting or reinforcing feelings (generally of displeasure): "I presume she's telling him about Aoife, who's, like, still in hospital”; or "I can see Claire’s eyes, roysh, just, like, welling up with, like, tears”. In these cases like can be seen as a hedge, mitigating or reducing the impact of the assertion, a tendency that Murphy's data (2010: 82-83), which accounts for gender-related variation in the use of hedging, also strongly supports. Focuser like is also used for exaggerations such as: “[...] a bubble jacket that's, like, five sizes too big for her"; "JP turns the heat up again. It must be, like, a hundred degrees in the jammer at this stage” (cf. Andersen, 2000: 25). And it is used when describing unusual actions (“[...] two days ago I got, like, a text message from him”), or surprising events (“Hang on, is this, like, blackmail?”). 
One of the aspects of this marker noted by Schourup (1985) in relation to AmE is that it is used in connection with quantifiable units, indicating approximation, with the meaning that no exactness is intended. In that sense like is close in meaning to "roughly" or "approximately” and it can be replaced by these adverbs. Examples of this in the novel are:

“No Matter What' was, like, our song, even though we were only together for, like, ten minutes, which, incidentally, was a record for me".

"Hey, that was, like, two years ago".

“[...] he was just stood there for, like, twenty minutes, staring at it like a total spacer”.

By using like in these examples, the narrator presents time as a rough approximation, and keeps from offering a more precise account of time that would be unnecessary. In conversation, listeners would assume that ten minutes, two years ago and twenty minutes are an approximate temporal description of the event referred to, and not an accurate account of what is being talked about (cf. Andersen, 2000: 22). Such accuracy is not called for and might make the speaker sound pedantic, provoking rejection on the part of the hearer. By contrast, this use of like seeks to shorten the distance between interlocutors and may be perceived as a search for bonding between the speaker and the hearer (see Murphy, 2010: 81). In that sense, it could be argued that the same effect is achieved by the narrative voice in CIDN, where this loose reference to time brings the narrator closer to the reader, as if a dialogue between Ross and the reader had in fact been established from the outset, positioning the reader as the hearer. This is also concomitant with the findings of Jücker and Smith (1990), and Müller (2005), who report that in their data friends used like significantly more often than strangers. Indeed, the incorporation of this feature into the narrative creates that sense of intimacy that exists in conversations between friends, shortening the distance between narrator and readers. This type of bonding is also manifest in the use of roysh, (the phonetic representation of DM right, as pronounced by the Dublin characters in the novel), whose occurrence also features very high in the novel (1075 tokens in total). Although space does not allow for a more detailed discussion of roysh, it is worth mentioning that both DMs are found to perform similar functions in certain contexts ("So all of a sudden there I am, roysh, eleven o'clock in the morning, sitting in a kitchen in darkest Knackeragua, roysh, watching Tina's old man make fried bread"). The use of both roysh and like then, contributes to constructing the narration in a convincing fashion, and is one of the devices deliberately employed by Howard to build rapport with the reader, who is able to recognise this use of both DMs as a feature of current spoken Dublin English (DubE).

An attempt to be deliberately imprecise can also be observed in the example "I saw she was wearing this, like, nightdress, and it was, like, pink”, which conveys a certain element of looseness in the description of the dress. The use of like here indicates that the speaker is 
opting for a loose interpretation of the object described, both in terms of the type of garment and its colour, and that his description of it is not to be taken too literally. This is in fact, closely related to the tendency to avoid strong manifestations of assumptions which is characteristic of IrE (cf. Farr, 2005; Martin, 2005). Like in this case allows the narrator to present his information without sounding too assertive, a way of expressing indirectness which is often attributed to this variety (see also Murphy, 2010: 47-84). Hedging in this case also helps the author to project a more authentic image of his character.

Within a (variational) sociolinguistic framework (see Barron and Schneider, 2005), Howard's perception of the speech of the community he depicts in his novel seems to indicate that the use of the DM like is one of the features used by young south Dubliners as a mark of urban sophistication, contributing to their dissociation from north-Dublin local speech. Although the dispersion plot in Figure 5 shows that the use of like is traceable throughout the entire novel, the majority of the examples of like come from the narrator's voice, only 48 occurrences appear in the speech of other (South Dublin) characters. In other words, it is Ross and his friends, and not the characters from the north-side of Dublin, who employ this DM.

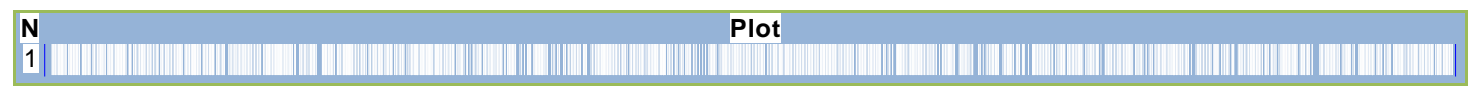

Figure 5. Dispersion plot of like in CIDN

If, as suggested above, close examination of contemporary writing often helps us find out about current language use, one question to be asked is whether the uses of the DM like referred to above could be indicative of what Hickey (2003) has referred to as supraregionalisation, whereby a particular language variety loses specifically local features and becomes less regionally bound (Hickey, 2003: 351). Andersen (2001: 209) attributes nonfinal position uses of like to the influence of AmE. However, since this seems to be a relatively new development in the speech of certain DubE speakers, it would appear that the adoption of this feature may have been influenced by its spread in British English dialects in more recent times. Certainly, if this rise of clause-medial like is indeed indicative of real spoken DubE, then this particular urban variety would clearly be moving from more vernacular to more globalised uses of like.

\section{CONCLUSIONS}

This detailed look at the use of like in CIDN aims at providing new insights into current Irish writing. A close study of the language of a text like this, especially using corpus techniques which analyse the language of the entire novel, may be a valuable contribution not only to the criticism of the work of contemporary Irish authors such as Howard, but also to the 
description of contemporary spoken IrE in so far as it shows the characteristics and functions of a fashionable DM that might either disappear or evolve into something different through language use in the future.

The paper started by arguing that literary data can serve as a useful source of information for language analysis. Indeed, the examination of changes in the use of DMs in Irish writing is a good way of investigating which particular markers are being replaced by new forms as part of the continual lexical renovation of certain pragmatic functions which may or not survive in the future. At present, Howard's depiction of contemporary spoken IrE shows that the use of like as a DM is quite robust. The fact that he resorts to this feature responds to a deliberate attempt to create identification and make his work attractive to its target audience. By the recurrent insertion and satirisation of the DM like, which is strongly associated with certain DubE speakers, his readers may feel they are being addressed in a narrative voice that they are able to recognise. Also by replicating the use of like in such an accurate manner (that is, in terms of functions), he manages to build some sort of rapport with the reader (even with those who might find some of the character's ideas outrageous). The reader, thus, sees in Ross's stories the voice of a potential "buddy" (for whom one might even feel sorry).

Although arguably repetitive and "stylistically poor", the use of the DM like allows Howard to construct a coherent pattern of speech characterization that the reader soon gets accustomed to and identifies as meaningful. The merit of the author is that this pattern is successfully developed throughout the novel without diverting attention away from the story, while appealing to shared linguistic knowledge between the two interlocutors that partake in the narration: the narrator and the listener, or the author and his readership.

\section{ACKNOWLEDGEMENTS}

I am grateful to Anne O’Keeffe, Fiona Farr, Kevin McCafferty and Gisle Andersen for their comments on an earlier draft of this paper, and to MA students in the universities of Extremadura, Limerick and Bergen, for their interest and enthusiasm in the topic.

\section{NOTES}

1. See Language and Literature Special Issue, vol. 10 (2) May 2001.

2. For a discussion of the term discourse marker see Romero Trillo (2006).

3. Example provided by Kallen (2006). Unless otherwise indicated, all the examples included here come from The Curious Incident of the Dog in the Nightdress.

4. Howard claims that his journeys on the 46A bus and the Dart are primary sources for the character and events: http://www.rte.ie/tv/tubridytonight/av_20090404.html?2520705,null,228 


\section{REFERENCES}

Adolphs, S. (2006). Introducing Electronic Text Analysis: A Practical Guide for Language and Literary Studies. London: Routledge.

Adolphs, S. \& Carter, R. (2002). Corpus stylistics: point of view and semantic prosodies in To the Lighthouse, Poetica 58, 7-20.

Amador Moreno, C. P. (2005). Discourse Markers in Irish English: an example from Literature. In Barron, A. \& K.P. Schneider (Eds.), The Pragmatics of Irish English (pp. 73-100). Berlin: Mouton de Gruyter.

Amador Moreno, C.P. \& Nunes, A. (2009). Introduction. In C. P. Amador Moreno \& A. Nunes (Eds.), The Representation of the Spoken Mode in Fiction (pp. 1-13). Lewiston, New York: The Edwin Mellen Press.

Amador Moreno, C.P. \& O’Keeffe, A. (2009). From arrah to like: Irish English discourse markers in fictional and non-fictional corpora. Paper presented at the IVACS Annual Symposium. University of Edinburgh, Scotland, January.

Andersen, G. (1997). They like wanna see like how we talk and all that. The use of like as a discourse marker in London teenage speech. In M. Ljung (Ed.), Corpus-based Studies in English (pp. 3748). Amsterdam: Rodopi.

Andersen, G. (1998). The pragmatic marker like from a relevance-theoretic perspective. In A. H. Jucker \& Y. Ziv (Eds.), Discourse Markers: Descriptions and Theory (pp. 147-170). Amsterdam/Philadelphia: John Benjamins.

Andersen, G. (2000). The role of pragmatic marker like in utterance interpretation. In G. Andersen \& T. Fretheim (Eds.), Pragmatic Markers and Propositional Attitude (pp. 17-38). Amsterdam: John Benjamins.

Andersen, G. (2001). Pragmatic Markers and Sociolinguistic Variation: A Relevance-Theoretic Approach to the Language of Adolescents. Amsterdam: Benjamins.

Baker, P. (2007). Using Corpora in Discourse Analysis ( $2^{\text {nd }}$ ed.). London/New York: Continuum.

Barron, A. \& Schneider, K. (Eds.) (2005). The pragmatics of Irish English. Berlin: Mouton de Gruyter.

Buchstaller, I. \& D’Arcy, A. (2009). Localized globalization: A multi-local, multivariate investigation of 'be like'. Journal of Sociolinguistics, 13, 291-331.

Buchstaller, I. (2001). An alternative view of like: Its grammaticalisation in conversational American English and beyond. Edinburgh Working Papers in Applied Linguistics 11, 21-41.

Carter, R. (1999). Common language: corpus, creativity and cognition. Language and Literature, 8(3), 195-216.

Carter, R. (2004). Language and Creativity. The Art of common Talk. Abingdon and New York: Routledge.

Chambers, J. K. (1995). Sociolinguistic Theory. Oxford: Blackwell.

Cohen Minnick, L. (2001). Jim's language and the issue of race in Huckleberry Finn. Language and Literature, 10(2), 111-128.

Culpeper J. \& Kytö, M. (1999). Investigating Nonstandard Language in a Corpus of Early Modern English. Methodological Considerations and Problems. In I. Taavitsainen, G. Melchers \& P. Pahta (Eds.), Writing in Nonstandard English (pp. 171-187). Amsterdam/Philadelphia: John Benjamins.

Culpeper, J. (2002). Computers, language and characterisation: An analysis of six characters in Romeo and Juliet. In U. Melander-Marttala, C. Östman \& M. Kytö (Eds.), Conversation in Life and in Literature (pp. 11-30). Uppsala: Universitetstryckeriet.

Culpeper, J. (2009). Keyness words, parts-of-speech and semantic categories in the character-talk of Shakespeare's Romeo and Juliet. International Journal of Corpus Linguistics, 14(1), 29-59.

D’Arcy, A. (2005). Like: Syntax and development. Unpublished Doctoral Dissertation, University of Toronto, Canada.

Dailey-O'Cain, J. (2000). The sociolinguistic distribution and attitudes towards focuser like and quotative like. Journal of Sociolinguistics, 4, 60-80. 
Dragger, K. (2006). Social Categories, Grammatical Categories, and the Likelihood of 'Like' Monophthongisation. In P. Warren \& C. I. Watson (Eds.), Proceedings of the 11th Australian International Conference on Speech Science \& Technology. Auckland: Australian Speech Science \& Technology Association Inc.

Farr, F. (2005). Relational strategies in the discourse of professional performance review in an Irish academic environment: The case of language teacher education. In K. P. Schneider \& A. Barron (Eds.), Variational Pragmatics: The Case of English in Ireland (pp. 203-234). Berlin: Mouton deGruyter.

Farr, F. \& O’Keeffe, A. (2002). Would as a hedging device in an Irish context: an intra-varietal comparison of institutionalised spoken interaction. In R. Reppen, S. Fitzmaurice \& D. Biber (Eds.), Using Corpora to Explore Linguistic Variation (pp. 25-48). Amsterdam: John Benjamins.

Farr, F., Murphy, B. \& O’Keeffe, A. (2002). The Limerick corpus of Irish English: Design, description and application. Teanga, 21, 5-29.

Ferrara, K. \& Bell, B. (1995). Sociolinguistic variation and discourse function of constructed dialogue introducers: The case of be like. American Speech, 70, 265-289.

Halliday, M. A. K. (1971). Linguistic Function and Literary Style: An enquiry into the language of William Golding's 'The Inheritors'. In S. Chatman (Ed.), Literary Style: A Symposium (pp. 362400). New York: Oxford University Press.

Hickey, R. (2003). How and why supraregional varieties arise. In M. Dossena \& Ch. Jones (Eds.), Insights into Late Modern English (pp. 351-73). Frankfurt: Peter Lang.

Hickey, R. (2005). Dublin English. Evolution and Change. Amsterdam: John Benjamins.

Hickey, R. (2007). Irish English. Its history and present-day forms. Cambridge University Press.

Hori, M. (2004). Investigating Dickens' Style. A Collocational Analysis. Basingstoke: Palgrave Macmillan.

Johnstone, B. (1991). Discourse-level aspects of dialect in fiction: A Southern American Example. Language and Style, 24(4), 461-471.

Jucker, A. \& Smith, S. (1998). And people just you know like 'wow': Discourse markers as negotiating strategies. In A. Jucker \& Y. Ziv (Eds.), Discourse Markers: Descriptions and Theory (pp. 171201). Amsterdam: John Benjamins.

Kallen, J. L. (2006). Arrah, like, you know: The dynamics of discourse marking in ICE-Ireland. Paper presented at the $16^{\text {th }}$ Sociolinguistics Symposium, University of Limerick, Ireland, July.

Kiberd, D. (2002). Inventing Ireland. The Literature of the Modern Nation ( $2^{\text {nd }}$ ed.). London: Random House.

Levey, S. (2006). The sociolinguistic distribution of discourse marker like in preadolescent speech. Multilingua, 25, 413-44.

Louw, B. (1997). The role of corpora in critical literary appreciation. In A. Wichmann et al. (Eds.), Teaching and Language Corpora (pp. 240-51). London: Longman.

Macaulay, R. (2005). Talk that Counts: Age, Gender and Social Class Differences in Discourse. Oxford: Oxford University Press.

Mahlberg, M. (2007a). Clusters, key clusters and local textual functions in Dickens. Corpora, 2(1), 131.

Mahlberg, M. (2007b). Corpus stylistics: bridging the gap between linguistic and literary studies. In M. Hoey, M. Mahlberg, M. Stubbs \& W. Teubert (Eds.), Text, discourse and corpora (pp. 191218). London: Continuum.

Martin, G. (2005). Indirectness in Irish-English business negotiation: A legacy of colonialism. In K. P. Schneider \& A. Barron (Eds.), Variational Pragmatics: The Case of English in Ireland (pp. 235-268). Berlin: Mouton deGruyter.

McCarthy, M. J. (2002). Good listenership made plain: British and American non-minimal response tokens in everyday conversation. In R. Reppen, S. Fitzmaurice \& D. Biber (Eds.), Using corpora to explore linguistic variation (pp. 49-71). Amsterdam: John Benjamins.

McCarthy, M. (1993). Spoken discourse markers in written texts. In J. M. Sinclair, M. Hoey \& G. Fox (Eds.), Techniques of Description: Spoken and Written Discourse. A Festschrift for Malcolm Coulthard (pp. 170-182). London: Routledge.

(C) Servicio de Publicaciones. Universidad de Murcia. All rights reserved. IJES, vol. 12 (2), 2012, pp. 19-38 Print ISSN: 1578-7044; Online ISSN: 1989-6131 
McEnery, A., Xiao, R. \& Tono, Y. (2006). Corpus-Based Language Studies. London and New York: Routledge.

Miller, J. \& Weinert, R. (1995). The function of like in dialogue. Journal of Pragmatics, 23, 365-393.

Müller, S. (2005). Discourse Markers in Native and Non-native English Discourse. Amsterdam/Philadelphia: John Benjamins.

Murphy, B. (2010). Corpus and Sociolinguistics. Investigating age and gender in female talk. Amsterdam/Philadelphia: John Benjamins.

Murphy, B. (2004). Well, you know, shur: the influence of age on the use of pragmatic markers in spoken discourse. Paper presented at the CALS Conference, University of Limerick, Ireland, June.

O'Carroll-Kelly, R. (pseud. of Paul Howard) (2005). The Curious Incident of the Dog in the Nightdress. Dublin: Penguin Ireland.

O’Halloran, K. (2008). Corpus-assited literary evaluation. Corpora, 2(1), 33-63.

O'Keeffe, A. (2005). 'You've a daughter yourself? A corpus-based look at question forms in an Irish radio phone-in. In K. P. Schneider \& A. Barron (Eds.), Variational Pragmatics: The Case of English in Ireland (pp. 339-366). Berlin: Mouton deGruyter.

Romaine, S. \& D. Lange. (1991). The use of like as a marker of reported speech and thought: A case of grammaticalization in progress. American Speech, 66, 227-279.

Römer, U. (2006). Where the computer meets language, literature, and pedagogy: Corpus analysis in English Studies. In A. Gerbig \& A. Müller-Wood (Eds.), How Globalization Affects the Teaching of English: Studying Culture Through Texts (pp. 81-109). Lampeter: The Edwin Mellen Press.

Romero Trillo, J. (2006). Discourse Markers. In K. Brown (Ed.), Encyclopedia of Language \& Linguistics ( $2^{\text {nd }}$ ed.) (pp. 639-642). Oxford: Elsevier.

Schneider, E. W. (2002). Investigating variation and change in written documents. In J. K. Chambers, P. Trudgill \& N. Schilling-Estes (Eds.), The Handbook of Language Variation and Change (pp. 67-96.). Oxford: Blackwell.

Schourup, L. (1985). Common Discourse Particles in English Conversation. New York: Garland.

Scott, M. (1999). WordSmith Tools, version 3.0. Oxford: Oxford University Press.

Scott, M. (2006). Key words of individual texts. In M. Scott \& C. Tribble, Textual Patterns: Key Words and Corpus Analysis in Language Education (pp. 55-72). Amsterdam: John Benjamins.

Semino, E. \& Short, M. (2004). Corpus Stylistics. Speech, Writing and Thought Presentation in a Corpus of English Writing. London and New York: Routledge.

Siemund, P., Maier, G. \& Schweinberger, M. (2009). Towards a more fine-grained analysis of the areal distribution of non-standard features of English. In E. Penttilä \& H. Paulasto (Eds.), Language Contacts Meet English Dialects (pp. 19-46.). Cambridge: Cambridge Scholars.

Simpson, P. (1997). Language through Literature. London: Routledge.

Simpson, P. (2004). Stylistics. London: Routledge.

Sinclair, J. (2003). Intuition and annotation - the discussion continues. In K. Aijmer \& B. Altenberg (Eds.), Language and Computers. Paper presented at the $23^{\text {rd }}$ International Conference on English Language Research on Computerized Corpora (ICAME 23). Göteborg.

Starcke, B. (2006). The phraseology of Jane Austen's Persuasion: phraseological units as carriers of meaning. ICAME Journal, 30, 87-104.

Stockwell, P. \& Wynne, M. (2006). Corpus Stylistics: a public inquiry. Paper presented at the 3rd International IVACS Conference, University of Nottingham, England, June.

Stubbs, M. (2005). Conrad in the computer: Examples of quantitative stylistics methods. Language and Literature, 14(1), 5-24.

Tagliamonte, S. \& D'Arcy, A. (2004). He's like, she's like: The quotative system in Canadian youth. Journal of Sociolinguistics, 8, 493-514.

Tamasi, S. (2001). Huck doesn't sound like himself: consistency in the literary dialect of Mark Twain. Language and Literature, 10(2), 129-144.

Tannen, D. (1980). Spoken/written language and the oral/literate continuum. In Proceedings of the Sixth Annual Meeting of the Berkeley Linguistic Society, 207-218. 
White, G. (2008). Using small and large corpora to investigate pragmatic markers in Irish English. Paper presented at the SS17 Symposium, University of Amsterdam, the Netherlands, April. 